\title{
Determining Factors Affecting Carbon Emissions by Panel Quantile Regressions Analysis in Visegrad Group
}

\section{Muhammad Shahbaz}

Beijing Institute of Technology

Kenan Illarslan ( $\square$ ilarslan@aku.edu.tr)

Afyon Kocatepe University: Afyon Kocatepe Universitesi https://orcid.org/0000-0002-5097-7552

Münevvere Yıldız

Afyon Kocatepe University: Afyon Kocatepe Universitesi

\section{Xuan Vinh Vo}

University of Economics Ho Chi Minh City

\section{Research Article}

Keywords: Carbon Emissions, Economic Growth, Bank Loans, Military Expenditures, Panel Quantile Regression, Visegrad Group

Posted Date: February 23rd, 2022

DOI: https://doi.org/10.21203/rs.3.rs-1365444/v1

License: (c) (i) This work is licensed under a Creative Commons Attribution 4.0 International License. Read Full License 


\title{
Determining Factors Affecting Carbon Emissions by Panel Quantile Regressions Analysis in Visegrad Group
}

\section{Muhammad Shahbaz}

School of Management and Economics Beijing Institute of Technology, China.

Institute of Business Research University of Economics Ho Chi Minh City, Vietnam

Email: $\underline{\text { muhdshahbaz77@gmail.com }}$

\author{
Kenan Ilarslan ${ }^{1}$ \\ Bolvadin Faculty of Applied Sciences \\ Afyon Kocatepe University, Turkey \\ Email: ilarslan@aku.edu.tr
}

\section{Münevvere Yildiz}

Bolvadin Faculty of Applied Sciences

Afyon Kocatepe University, Turkey

Email: munevvereyildiz@aku.edu.tr

\author{
Xuan Vinh Vo \\ Institute of Business Research and CFVG \\ University of Economics Ho Chi Minh City, Vietnam \\ Email: vxvinh@yahoo.com
}

\begin{abstract}
This study determines the impacts of gross domestic product, domestic bank credits given to private sector, and military expenditures on carbon emissions based on 1990-2019 time period. The panel quantile regression approach is applied for the Visegrád group countries. Our empirical results reveal that domestic bank credit given to private sector has a positive and meaningful impact on carbon emissions at medium and high quantile levels. On other hand, it has been determined that gross domestic product has a reducing impact on carbon emissions, but military expenditures have an increasing impact on carbon emissions. Besides, as consequences of such tests, the difference between the quantiles, that is, the heterogeneous structure was revealed. A separate model was created with a different panel quantile approach for robustness control, and the results were compared by giving different values to penalty term. These results provide strong evidence for decision-makers and implementers.
\end{abstract}

Keywords: Carbon Emissions, Economic Growth, Bank Loans, Military Expenditures, Panel Quantile Regression, Visegrad Group

\footnotetext{
${ }^{1}$ Corresponding author, ilarslan@aku.edu.tr, ORCID: 0000-0002-5097-7552
} 


\section{Determining Factors Affecting Carbon Emissions by Panel Quantile Regressions Analysis in Visegrad Group}

\section{Introduction}

Today, energy and fossil fuels being energy's raw material, which are used in the production and service sectors of economic activities and correlative activities aimed at increasing the quality of life of individuals, stand in front of us as big challenges today. The reason for this is that carbon emissions caused by fossil fuels used in energy production for such activities aimed at increasing human comfort and technological level is increasing day by day. The increase in carbon emissions implies and brings with it many problems. The most important of such problems is global warming as a result of greenhouse gas effect caused by increase in carbon emissions (Ustaoglu et al. 2021, Gul et al. 2015). Grave and critical climate changes as a result of global warming (Hapsoro and Ambarwati 2018, Sundblad et al. 2014, Hansen et al. 2013) and climate-related natural disasters (Rossati 2017, Kvaloy et al. 2012) raise concerns about the future of the world as a habitable place. In terms of net income loss triggered by decreased yields incidental to climate change caused by greenhouse gas emissions have reflections in a wide spectrum and potential adverse impacts on agricultural production (Dumortier and Elobeid 2021, Rehman et al. 2021), human health (Dong et al. 2021, Alahmad et al. 2020, Chen et al. 2017), access to water resources (Demirhan, 2020), biodiversity and forest ecosystem (Velepucha et al. 2016, Shahbaz et al. 2013).

Examining the factors affecting carbon emissions has been the subject of numerous academic studies. As discussed in this study, there is a common consensus that military expenditures have an increasing impact on carbon emissions. Indeed (Wang et al. 2021, Gokmenoglu et al. 2021, Ahmed et al. 2020, Johnstone and McLeish 2020, Afia and Harbi 2018, Bildirici 2017a, Sana and Neila 2016) indicate and denote that the capability of military spending to increase carbon emissions is based on the prevalent use of petroleum fuels in military departments. Most of the studies examining the connection between economic growth and carbon emissions are handled in the context of Environmental Kuznets Curve (EKC) hypothesis. The EKC hypothesis deals with the connection between per capita income and environmental deterioration i.e. "invertedU" type relationship between environmental pollution and per capita income. That is to say, when economic growth increases, environmental pollution initially increases; after a certain threshold value, the trend reverses as economic development increases, environmental awareness is also heightened; thus, environmental pollution decrease (Tenaw and Beyene 2021, Leal and Marques 2020, Shahbaz 2019, Rana and Sharma 2019, Wang et al. 2015, Acaravci and Ozturk 2010). There is mixed consensus in existing literature on the effect of domestic credit to private sector, which is used as an indicator of financial development in many studies, on carbon emissions. In other words, the findings acquired from studies examining the impacts of domestic credit to private sector on carbon emissions indicate two different results. First, domestic credit to private sector has an increasing impact on carbon emissions (Neog and Yadava 2020, Samour et al. 2019, Li and Ouyang 2019, Acheampong 2019). Accordingly, the increase in loans offered to the private sector due to increasing financial development and the efficiency increases in banking system have an increasing effect on carbon emissions. Secondly, domestic credit to private sector has a carbon emissions reduction effect (Lv and Li 2021, Yang et al. 2020, Lahiani 2020). This outcome is attributed to the governments of relevant countries encouraging financial system to implement environmentally friendly approaches via production process. 
Since no success has been achieved in reducing carbon emissions, it is very important to address the issue at an economic level and identify the factors that affect carbon emissions and define the measures that can be taken on the basis of countries. In this sense, the factors affecting carbon emissions for the Czech Republic, Hungary, Poland, and Slovakia, which are called the Visegrád Group (V4), have been taken into account. While Schmidt (2016) stated that the V4 formation has important advantages in the future by emphasizing its geopolitical position. Ivanova and Masarova (2018) evaluated that this constitution offers new and great opportunities for economic development as well as contributing to the creation of European security architecture. For example, according to 2020 data, the V4 formation has the 3rd most populous population in the $\mathrm{EU}^{2}$. Papiez (2013), on other hand, stated that it is necessary to question whether and to what extent the dynamic changes and economic growth in Central European countries, especially after the 1990 s, affect environment.

This study has been structured within the framework of the research question and contributes to existing literature by three folds: (i), This study investigates whether military expenditures, economic growth and financial development have an effect on carbon emissions. In doing so, the Visegrád Group of countries is considered to reach empirical evidence on how and in what direction such variables affect carbon emissions. (ii), The Kao and Westerlund panel cointegration approaches are applied to examine whether cointegration between the variables exists or not. (iii), This study applies PQR method to investigate the effects of military expenditures, economic growth and financial development have an effect on carbon emissions in the context of the V4 formation, which has the potential to become an important economic power in the future. The PQR method, one of the non-parametric methods, was used in the analyses, since the countries' data did not show normal distribution. The estimates of this method are considered more robust compared to estimates produced by standard least-squares method. Our empirical results note that military expenditures, economic growth and financial development have an effect on carbon emissions but military expenditures increase carbon emissions and such effects vary significantly in terms of size. Financial development has increasing effect on carbon emissions which is found to be significant at very few quantiles.

The rest of paper is organized as following: Section-II presents an overview of the relationship between military expenditures, domestic credit to private sector and economic growth, and carbon emissions based on a theoretical basis. Section-III describes the econometric methodology. The empirical results and their discussion are drawn in Section-VI. Section-V is combined with conclusion and policy implications.

\section{Literature Review and Hypothesis Development}

In line with the process of examining the factors affecting carbon emissions, many different variables have been used in existing literature. The most frequently used variables are economic growth (per capita income), economic complexity index, human development index, renewable energy, environmental technologies, income inequality, population, exports, and imports to GDP.

\section{II.I. Relationship between Economic Growth and Carbon Emissions}

In most of the studies carried out to observe the effects of the causes and consequences of carbon emissions in the economic framework, economic growth factor comes to the force. In the studies, the connection between carbon emissions and economic growth in countries with different levels of development was investigated. The link between economic growth and its

\footnotetext{
${ }^{2}$ https://www.worldometers.info/world-population/population-by-country/
} 
environmental effects has been evaluated within the structure of the EKC hypothesis in many studies. According to the EKC hypothesis, the priority of low-income countries would be mainly focused on food and shelter, and environmental factors are generally perceived as less important. With the increase in income level, individuals will become more sensitive and responsive to environment (Harbaugh et al. 2002). Various studies on economic growth and its environmental effects were pioneered by Grossman and Krueger (1991), Shafik and Bandyopadhyay (1992), and Panayotou (2003). The main point addressed by such studies is that economic growth is aimed at increasing production and economic growth at initial level, and environmental pollution will increase over time with the neglect of environmental factors. It is argued that with the advanced level of growth, environmental awareness will increase, and initiatives will be initiated to reduce environmental pollution. While some of such studies examining economic growth and carbon emissions have demonstrated the validity of the hypothesis, significant results have not been obtained in others. While Grossman and Krueger (1991), using panel data analysis method for 32 different countries, Shafik and Bandyopadhyay (1992) demonstrated the validity of the EKC hypothesis for the period of 1960-1990 for 149 countries. Panayotou (2003) conducted a study on developed and developing countries, Cole et al. (1997) conducted a study on OECD countries, and Shahbaz et al. (2016) conducted a study on Next-11 countries and they have thus demonstrated and stated the validity. Jebli et al. (2016) stated the validity of the hypothesis for OECD countries. Apergis and Ozturk (2015) examined 14 Asian countries for 1990-2011 and presented the validation of EKC hypothesis.

On other hand, from multi-country studies, Bakirtas and Cetin (2017) concluded that the hypothesis is not valid for MIKTA countries, Ozcan (2013) for middle-east countries, and Jaunky (2011) for 36 high-income countries. Koçak et al. (2020) examined the impacts of carbon emissions on the ten most visited countries in the world. They noted that economic growth has a positive impact on carbon emissions, and there is a one-way causality relationship between them. Similarly, Song et al. (2008) noted that the EKC hypothesis is valid for the Chinese economy. Jiang et al. (2021) applied ARDL, FMOLS, and CCR models and found that the short-run and long-term impacts of economic growth 'in China' on carbon emissions confirm the EKC hypothesis. Moreover, Wang et al. (2011) and He et al. (2017) note the absence of the EKC hypothesis for China at different periods. Similarly, Begum et al. (2015) for Malaysia, Alshehry and Belloumi (2017) for Saudi Arabia, Robalino-López et al. (2015) for Venezuela, reported the invalidation of the EKC hypothesis.

This shows the presence of economic growth and carbon emissions in the context of economic growth. The hypothesis developed based on this theoretical expectation can be expressed as follows:

$\mathrm{H}_{1}$ : There is a significant relationship between economic growth and carbon emissions.

\section{II.II. The Relationship between Financial Development and Carbon Emissions}

Another issue that is at the focus of interest of the study is the impact of financial development on carbon emissions. In many studies in existing literature, ratio of domestic credit to private sector to GDP is defined as the level of financial development. It is evaluated that the increase in bank loans offered to private sector contributes to sectoral development and expansion of production. However, it is very important how companies use this resource provide through banks. According to existing literature, the impact of bank loans on carbon emissions has been presented in two ways. Certain studies state that domestic credit to private sector has a negative impact on carbon emissions and causes an increase in emission values. For example, Tamazian et al. (2009) administered a panel-random effect model for BRIC economies, Xu et al. (2018) 
administered the ARDL-VECM model for Saudi Arabia, Nasir et al. (2019) administered panel DOLS and FMOLS models for ASEAN-5 countries, and Ahmad et al. (2020) used panel cointegration and Granger causality test for 90 belt and road countries revealed that the increase emissions is the companies' focus on increasing their earnings and their efforts to continuously increase production within this framework. The improvement in financial system may also cause an increase in carbon emissions for consumers. The increase in demand for products such as automobiles, refrigerators, and air conditioners is of utmost importance (Jalil and Feridun 2011). Ehigiamusoe and Lean (2019) considered countries from different income groups in their panel data analysis which was conducted on 122 different countries. They found that the impact of bank loans on carbon emissions to be positive. Their analysis further revealed that bank loans are reducing carbon emissions in high-income countries and as augmenting in lowand middle-income countries. Samour et al. (2019) reported that developments in banking sector can lead to an increase in investment and energy consumption, which in turn can lead to an increase in carbon emissions.

Moreover, the use of bank credit resources to invest in environmental technologies causes carbon emissions. Indeed, Brunnschweiler (2010) used GLS and GMM methods for non-OECD countries, Levine et al. (2018) used OLS for the USA, Nwani and Omoke (2020) used dynamic ARDL simulation for Brazil, and Tian et al. (2017) demonstrated the decrease in carbon emissions for the Chinese economy by using ARDL-ECM methods. Similarly, Bowman (2010), Chen (2013), and Campiglio (2016) stated that bank loans as an indicator of financial development would have a reducing impact on carbon emissions. This discussion also shows a relationship between domestic credit to private sector and carbon emissions. The hypothesis developed based on this theoretical expectation can be expressed as follows:

$\mathrm{H}_{2}$ : There is a significant relationship between bank loans given to the private sector and carbon emissions

\section{II.III. The Relationship between Military Expenditures and Carbon Emissions}

The extent and level of security of the people living in the country is as important as macroeconomic factors in ensuring economic welfare for each country. Domestic and foreign investments are made according to the atmosphere of confidence in the country. In this sense, every country that wants to increase its level of economic welfare allocates a significant share of its military expenditures in order to increase its security. This share, which is allocated in economic establishment, is used both to meet personnel expenses and to produce and purchase machinery and equipment. Tools and machinery used in military field produce energy with fossil fuels. The connection between economic growth and military expenditures will give us an idea on this subject. For example, Birdi and Dunne (2001), examining the link between economic growth and military expenditures, revealed that the relationship is negative in the short run but positive in the long run. Ahmed et al. (2020) obtained opposite results in Myanmar. Their results indicate that the level of military expenditures should be re-evaluated at the point of sustaining economic growth, and alternative energy conservation methods should be applied to reduce carbon emissions. Following the expression of the relationship between economic growth and military expenditures, it will be beneficial for countries to reveal the connection between carbon emissions and military expenditures. However, there are limited numbers of studies in existing literature examining the impact of military expenditures on carbon emissions. Sana and Neila (2016), in their study on military effort and pollution covering 121 countries, noted that military expenditures have a direct and indirect positive impact on carbon emissions. Afia and Harbi (2018) found that military expenditures have both direct and indirect positive 
effects on carbon emissions. Wang et al. (2021) investigated the connection between oil dependence, carbon emissions, and military expenditures for various countries by applying the Fourier ARDL model. They found the presence of cointegration relationship between the variables for China, India, and Italy, no relationship was found in the USA, France, and other countries. Solarin et al. (2018) examined the effect of military spending on emissions in the United States with various probability-based time-series approaches. They reported that military expenditures have been found to have a hybrid effect on carbon emissions. Bildirici (2017a, b, c, d), who conducted one of the first studies on the subject, revealed the connection between military expenditures and carbon emissions for different countries. In the USA, Bildirici (2017a) revealed a positive relationship by applying the bounds testing approach. They also found a unidirectional causal connection from military expenditures to carbon emissions. Bildirici (2017b) used the ARDL test and the DOLS, FMOLS, and CR methods, and Toda and Yamamoto causality method for the USA. A long-term cointegration relationship was determined between biofuel consumption, economic growth, military expenditures and carbon emissions, and a unidirectional causality relationship was observed from military expenditures to carbon emissions. In his study using the variables of carbon emissions, economic growth, military expenditures and energy consumption for G7 countries, Bildirici (2017c) determined the cointegration relationship between the variables and found a one-way causality relationship from military expenditures to carbon emissions. Bildirici (2017d) also investigated the factors affecting carbon emissions for Brazil, China, and the USA. The ARDL, FMOLS, DOLS, and CCR models and Toda and Yamamoto methods were used to determine the causality connection between the variables. They found the presence of a unidirectional causal relationship running from carbon emissions from military expenditures. Bargaoui and Nouri (2017) aimed to test various theories for the period of 1980-2010 by applying the dynamic panel data analysis on 114 countries. Their empirical analysis indicated that the effect of military expenditures on carbon emissions was found to be negative at the point of revealing the Treadmill of Production theory. Ullah et al. (2021) investigated the asymmetric effects of military expenditures on economic growth and environmental deterioration using the NARDL method using data from Pakistan and. They noted that in the long run, an increase in military expenditures in Pakistan and India reduces carbon emissions. Their empirical results also showed that the connection between military expenditures and economic growth and military expenditures and carbon emissions has an asymmetry for both countries. This discussion also mentions an important association between military expenditures and carbon emissions which helps us in developing a hypothesis as following:

$\mathrm{H}_{3}$ : There is a significant relationship between military expenditures and carbon emissions

\section{Econometric Methodology \\ III.I. The Data}

The annual data is used for empirical analysis covering the period of 1990-2019. The endogenous variable is carbon emissions, and the exogenous variables are domestic credit to private sector, GDP per capita and military expenditures. All data is included in empirical analyzes transformed into their natural logarithms. A data set consisting of 120 observations in total for the 30 years is longer $(T=30)$ period of Visegrád countries. However, due to the missing data in some years, the data set shows unbalanced panel data characteristics. Eviews $11 \mathrm{SE}$, Stata 16.1, and R programs were used for statistical and econometric analysis. Abbreviations, definitions, and sources related to the variables are presented in Table 1.

Table 1 Insert here 


\section{III.II. Econometric Method}

In the study, the fixed effect PQR analysis method will be used in order to measure the impact of lndcps, lnpgdp, and lnmiex on $\operatorname{lnco}_{2}{ }^{3}$. Using PQR methodology, we can examine the determinants of carbon emissions across the conditional distribution in the Visegrád group of countries. In the meantime, traditional regression techniques focus on averaging effects, which can lead to underestimation or overestimation of the relevant coefficient and even failure to detect significant relationship (Zhu et al. 2016). Therefore, PQR with fixed effects will be used, which makes it possible to estimate the conditional heterogeneous covariance effects of carbon emissions causes and thus to control for unobserved individual heterogeneity. The panel econometrics specification used is the Method of Moments Quantile Regression (MM-QR) developed by Machado and Silva (2019). One of the major advantages of this method is that the fixed effect includes an effect not presented in the traditional mean regression model, which enables them to capture the distributional heterogeneity of the endogenous variable's relationship with the exogenous variables in different quantile distributions (Usman et al. 2020, D'Orazio et al. 2020, Aziz et al. 2020). In other words, it allows us to determine the conditional heterogeneous covariance effects of the determinants of dependent variable by allowing individual impacts to affect the entire distribution. Machado and Silva (2019) expressed the quantile regression for the $\mathrm{X}$ variable belonging to the position-scale family in estimating the conditional quantiles as follows:

$$
Y_{i t}=\alpha_{i}+X_{i t}^{\prime} \beta+\left(\delta_{i}+Z_{i t}^{\prime} \gamma\right) U_{i t}
$$

Here $P\left\{\delta_{i}+Z_{i t}^{\prime} \gamma>0\right\}=1 .\left(\alpha, \beta^{\prime}, \delta, \gamma^{\prime}\right)^{\prime}$ is the probability of the predicted parameters. Moreover, as denoted by $\left(\alpha_{i}, \delta_{i}\right), i=1, \ldots, n i$ stands for individual fixed effects, and $Z$ is a $k$-vector expressed by $l$ element of differentiable transformations of the components of $X$.

$$
Z_{l}=Z_{l}(X), l=a, \ldots, k
$$

$X_{i t}$ is independent and uniformly distributed within the framework of each constant $i$ and the independent time $(t)$ element. $U_{i t}$ is identically distributed over individual $i$ and independent over time and is orthogonal to $X_{i t}$. Based on this information, the quantile regression of moments is expressed as follows:

$$
Q_{Y}(\tau \mid X)=\left(\alpha_{i}+\delta_{i} q(\tau)\right)+X_{i t}^{\prime} \beta+Z_{i t}^{\prime} \gamma q(\tau)
$$

Provided that $Q_{Y}(\tau \mid X)$ shows $Y$ dependent variable's quantile distribution, $\left(\alpha_{i}+\delta_{i} q(\tau)\right)$ shows the scalar effect. Given that $q(\tau)$ is the $\tau$-th quantile, estimation is solved by optimization of the following problem:

$$
\min _{q} \mathfrak{a}_{i} \stackrel{\circ}{\mathrm{a}}_{t} \rho_{\tau}\left(R_{i t}-\left(\delta_{i}+Z_{i t}^{\prime} \gamma\right) q\right)
$$

$\rho_{\tau}(A)=(\tau-1) A I\{A £ 0\}+T A I\{A>0\}$ denotes for and demonstrated check function.

\footnotetext{
${ }^{3}$ In order to determine the most appropriate econometric specification, Hausman test was performed and fixed effects model was preferred according to Chi-Square statistics (94.16), $\mathrm{p}$-value $=0.000$.
} 


\section{Empirical Analysis and Findings}

The results of the basic statistical tests performed to obtain preliminary information about the variables and to understand the relationship between them are presented in Table 2.

Table 2 Insert here

The fact that the mean and median values are the same or close to each other in a data set indicates that this distribution is symmetrical, which gives a clue that the variables have a normal distribution. Another a priori clue as to whether the data has a normal distribution or not is that the skewness and kurtosis values are close to 0 and 3 (You et al. 2017). However, as seen in Table 1, all the variables' skewness and kurtosis values are far from these values. Besides, according to the consequences of Jarque-Bera test, none of the variables are normally distributed at $1 \%$ and $10 \%$ significance levels, except for military expenditures. Another tool we can use at this point is Q-Q chart. The Q-Q chart is a probability plot that can visually show whether the data fit normal distribution. If the points seen on Q-Q graph coincide with the $y=x$ line, this means that the data are normally distributed (Xu and Lin 2020, Lin and Xu 2018). Otherwise, it is understood that the distribution of the data is skewed. Fig.1 shows the Q-Q probability distribution graphs of the variables. The fact that the data do not satisfy the assumption of normality is an obstacle to the use of least squares regression. For this reason, the quantile regression approach, which stretches this assumption, was used in the study.

\section{Fig 1 Insert here}

Fig. 1 shows that the distribution of all variables except lnmiex does not exactly coincide with the $\mathrm{x}=\mathrm{y}$ line, and therefore, these variables are not normally distributed. According to another result shown in Table 2, lnmiex has the highest standard deviation among the variables. As a matter of fact, the biggest difference between the maximum and minimum values belongs to this variable. The panel data are used to test for the existence of a unit root, cross-sectional dependence needs to be tested. If the cross-sectional dependency is rejected in panel data set, 1 st generation unit root tests can be used. If there is a cross-section dependency, using the 2nd generation unit root tests can enable us to make more consistent, effective, and powerful estimations (Çınar, 2011). According to the results of the cross-sectional dependency tests presented in Table 3, there is cross-sectional dependence for all variables. According to this result, it is appropriate to apply 2 nd generation panel unit root tests to test the stationarity of the variables. As stated in their studies (Khraief et al. 2020, Mercan et al. 2015), by taking the average of unit root test statistics (CADF) of each cross-section (country), the unit root test statistics for the panel as a whole, CIPS (Cross-Sectionally IPS) can be obtained.

Table 3 Insert here

Table 4 Insert here

The results of the CIPS unit root test show that the null hypothesis is rejected for all variables at first-rank differences. Therefore, the CIPS unit root test results indicate that all variables exhibit non-stationary behavior at the level and stationary behavior at the first-rank difference. In other words, all variables are integrated in relation with the order of I(1). At this stage, whether there is a long-term equilibrium connection between the variables was investigated with the first generation Kao panel cointegration test and Westerlund panel cointegration tests from the second generation tests. These cointegration tests were preferred in analyzes because they can be used for unbalanced panel data, and they require the time dimension $(\mathrm{T})$ to be larger 
than the unit size (N) (Tatoğlu, 2018). Table 5 presents the cointegration test results of these methods.

\section{Table 5 Insert here}

According to Kao panel cointegration test results, $\mathrm{H}_{0}$ hypothesis stated that there is no cointegration, was rejected, and it was accepted that there was a cointegration connection between the variables. In the next stage, the Westerlund test, one of the second generation panel cointegration tests, was performed, and the results are presented in Table 5. According to these results, $\mathrm{H}_{0}$ hypothesis stating that there is no cointegration between the variables was rejected. Accordingly, it has been observed that there is a cointegration connection between lnco 2 and lndcps, lnpgdp, and lnmiex. According to these results, it has been proven that there is a cointegration relationship between the variables according to both the first generation panel cointegration test Kao and the second generation panel cointegration test Westerlund. As stated by Gujarati, (2011), there is only one case where the regression of a non-stationary time series according to another non-stationary time series does not result in a spurious regression. This is the case of cointegration. If two-time series have stochastic trends (that is, they are not stationary), regression of one with respect to other will be able to balance these stochastic trends and reveal that there is a long-run equilibrium relationship between the two even if the two series are not stationary. Greene (2019) stated that in the case of a cointegrated relationship between the variables, it would be inefficient to take the differences of data because it would hide the long-term relationship between the variables. For these reasons, the variables were included in the panel quantile regression analysis with their level values. Indeed, Bilgili et al. (2021), Anwar et al. (2021), Gomez and Rodrigues (2020), Xu and Lin (2020), Mikayilov et al. (2020), Huang et al. (2020), Su et al. (2019), Loganathan et al. (2019) and Hsien et al. (2017) participated in the regression analyzes with the level values of the variables that have a cointegration relationship between them.

The Quantitative regression is frequently used, especially when the assumptions required for least squares regression are not met. There are quite a number of studies in existing literature on the application of the quantile regression approach to panel data. One of such approaches is expressed by Machado and Silva (2019) (MM-QR Estimation). Machado and Silva (2019) propose an estimator of the conditional quantiles obtained by combining the estimates of the position and scale functions defined as the conditional expectations of the variables, taking into account the conditional location-scale models. The advantage of this approach is that it only allows valid methods to be used for estimating conditional means. Table 6 presents the results of the fixed-effect panel quantile approach presented by Machado and Silva (2019), and the results are discussed below. Accordingly, lndcps in the formation of Visegrád group generally have a positive impact on Inco2. This impact is statistically significant in all other quantiles except the 1st and 2nd quantile levels. It is observed that this effect exhibits an increasing trend. In this context, Indcps in V4 group countries have an increasing effect on lnco2. In other words, financial ecosystem in these countries operates in a way that increases carbon emissions. The effect of lnmiex on $\operatorname{lnco}_{2}$ in such countries is positive and statistically significant at all quantile levels. However, it can be said that this effect is homogeneous at different quantile levels. Accordingly, military equipment and equipment in Visegrád group of countries have an effect that increases carbon emissions because they are currently equipped with the technological features of the old eastern bloc. However, considering the possibility of V4 group countries to include more modern and electronic military equipment in their military structure in the context of integration with the EU, NATO, and the western world, this effect can be expected to tend to decrease in the future. Furthermore, these countries' lnpgdp variable has a negative and meaningful impact on lnco2 at all quantile levels. Accordingly, people in Visegrád group 
countries contribute to the reduction of carbon emissions by making more conscious consumption and investment choices as their income increases. The tests performed to understand whether the coefficient values obtained at different quantile levels differ or not, and their results are presented in Table 7. In Table 7, Delta test and HAC robust test statistics are statistically meaningful at $1 \%$ and $5 \%$ levels. Therefore, $\mathrm{H}_{0}$ hypothesis, which is expressed as equal slopes along the quantiles, is rejected. This finding can be interpreted as evidence that the relationship between explained and explanatory variables varies across different quantiles.

Table 6 Insert here

Table 7 Insert here

In the study, the general status of factors affecting carbon emissions throughout the quantiles was presented in Table 6 with the fixed effect PQR method proposed by Machado and Silva (2019). Two robustness methods were considered at this stage of the study to test the validity of the results obtained. The model will be reconstructed using the fixed-effect PQR approach, the first of which was proposed by Koenker (2005). By this means, the results of two PQR models will be compared. Secondly, coefficients will be calculated by PQR for different penalty term parameters and evaluated. In this context, fixed effect PQR can be shown as follows (Barunik and Cech 2021, Khan et al. 2020, Singh and Kannadhasan 2020, Chen and Lei 2018). Fixed-effect PQR has a key problem with the presence of significant fixed-effects and is owing to the random parameter problem. There will be discrepancy when individuals head for infinity, but there are fixed observations for each cross-section. The use of fixed effect is to remove unobserved effects of fixed effects. The reliability of these methods is based on the fact that expectations are linear, which is not the cause of conditional quantities. To circumvent such problems, Koenker (2005) has proposed a suitable methodology in which the authors deal with unobservable fixed effects and fix them as a parameter to be estimated together with covariate effects for different quantities. In this method, calculation problems are minimized by using the penalty term of the estimation parameters as the parameter estimation. This term provides a better prediction by reducing the individual effects of the prediction coefficients in the model. Once the value of the penalty term approaches zero, the standard fixed-effects estimator is obtained, while when it approaches infinity, the estimation is performed without individual effects (Zhu et al. 2016). According to PQR results suggested by Koenker (2005) in Table 8, it is seen that the coefficients of lngdp and lnmiex variables are meaningful in all quantiles. It is seen that the impact of lngdp on lncoz is negative, while lnmiex variable is positive. This effect is heterogeneous at different quantile levels. The increase in lnmiex increases the amount of Inco 2 . This effect shows an increasing trend after this level, which decreases until the median quantile level. Therefore, this effect shows a heterogeneous feature at different quantile levels. According to the model, the coefficient of lndcps was found to be meaningful and positive only at the 8th quantile level. Therefore, empirical evidence for the impact of this variable on lncoz, which is the endogenous variable, is very limited.

\section{Table 8 Insert here}

In the method proposed by Koenker (2005), the penalty term parameter is evaluated as $\lambda=1$. However, although the effect of penalty term on the variables is intriguing, it will allow comparison with the results obtained, according to Machado and Silva (2019). Table 9 shows the PQR results with penalty function obtained for different values of $\lambda$. According to the results, $\operatorname{lnpg} d p$ variable revealed negative and statistically significant results for all $\lambda$ parameters and quantile levels. On other hand, Inmiex variable has an increasing effect on $\operatorname{lnco}_{2}$ at different 
penalty functions $(\lambda)$ and at all different quantile levels. This effect is statistically significant at most quantile levels. According to the fixed effect PQR results of Koenker with penal function, lndcps has a positive impact on lnco2, but it is meaningful at a small number of different quantile levels. In general, these two methods strongly support the effect of exogenous variables on carbon emissions, which is the endogenous variable, and the results obtained with Machado and Silva (2019) approach presented in Table 6 in terms of direction of this effect.

Table 9 Insert here

\section{Conclusions and Suggestions}

In this study, the factors affecting carbon emissions were investigated using PQR method for the formation of V4, using the period of 1990-2019. First of all, with the help of descriptive statistics, the general conditions of the variables were revealed, and it was observed that the assumption of normal distribution was not met. Afterward, the data stationarity was investigated by panel unit root tests, and it was determined that all series were stationary at the first difference. In order to see whether the variables will be included in the model with their level values, the existence of a long-term relationship was revealed by performing the panel cointegration test. PQR, which is the main method of the study, was analyzed within the framework proposed by Machado and Silva (2019).

According to the results obtained, while lndcps has a positive impact on lnco2, this effect is statistically significant at medium and high quantile levels. Accordingly, in V4 formation, the financial ecosystem transfers financial resources to private sector investments in a manner that increases carbon emissions. lnpgdp, on other hand, has a reducing effect on lnco2. This finding indicates that V4 countries have entered the second phase of the EKC curve. As a matter of fact, it can be said that individuals in such countries make consumption preferences to reduce lnco 2 due to their increasing environmental awareness and protectionist approaches with increasing income levels. Inmiex, on other hand, has a characteristic that increases lnco2. This finding may indicate a consequence of having old and exiguous technological military hardware and equipment. Delta test and HAC robust test statistics show that there is a difference between quantiles; that is, there is a heterogeneous structure for quantile levels. Another PQR method proposed by Koenker (2005) was used to confirm the robustness of these results. According to the method, lndcps, in general, have a meaningful positive effect only at the high quantile level, while lnpgdp has a negative effect and lnmiex have a positive significant effect at all quantile levels. PQR models performed by assigning different values to the penalty term, which is another robustness control method, also confirmed the results obtained above. Therefore, we have reached strong and robust empirical evidence for the magnitudes and signs of the coefficients obtained as a result of the econometric analysis. The effects on the coefficients of the variables used in the study, which are found to be significant on lnco2, are given in Fig. 2.

Fig 2 Insert here

We think that the results obtained from the study provide recommendations for decision-making authorities and implementors. In this context, first of all, financial ecosystem should be directed to private sector investments that reduces carbon emissions in the organization of V4. For this purpose, political decision-makers can manage this process with incentives or additional taxes during resource allocation. It can implement policies that protect the environment from pollution by implementing strategies that support sustainable energy use, such as lower credit costs and tax reductions on sustainable energy projects (e.g. biofuel production projects). The 
financial sector can contribute to the prevention of environmental pollution by providing financial resources for clean energy projects. Secondly, reductions in pollution can be achieved by increasing sustainable energy consumption in military activities and encouraging more innovation. Since traditional energy sources such as gasoline and diesel cause environmental degradation, public authorities should increase the use of sustainable energy by preparing the environment for the use of more environmentally friendly fuel types such as biofuels. The use of environmentally friendly engine technologies may be preferred in military vehicles and equipment. Moreover, military expenditures can contribute to environmental quality by including tools and equipment that work with electricity.

Acknowledgements We would like to thank the editor and anonymous referees for their invaluable comments, support, and patience.

Author Contribution M.Shahbaz: Supervision, investigation, K.Ilarslan and M.Yildiz: Material preparation, data collection, analysis and writing, X.V.Vo: Editing. All authors read and approved the final manuscript.

Funding This work did not receive any specifc grant from any funding agencies.

Availability of data and materials Data available at https://figshare.com/s/fd242755da8e44b95ede

\section{Declarations}

Ethics approval $\quad$ Not applicable.

Consent to participate Not applicable.

Consent for publication Not applicable.

Competing interests The authors declare no competing interests

\section{References}

Acaravci A, Ozturk I (2010) On the relationship between energy consumption, CO2 emissions and economic growth in Europe. Energy 35:5412-5420. https://doi.org/10.1016/j.energy.2010.07.009

Acheampong AO (2019) Modelling for insight: does financial development improve environmental quality? $\quad$ Energy 83:156-179. https://doi.org/10.1016/j.eneco.2019.06.025

Adebayo TS (2021) Testing the EKC hypothesis in Indonesia: Empirical evidence from the ARDL- based bounds and wavelet coherence approaches. Appl Economics J 28:78-100.

Afia NB, Harbi S (2018) The relationship between CO2 emissions and military effort. J of Economics Stud and Res, Article ID 342225. https://doi.org/10.5171/2018.342225

Ahmad M, Jiang P, Majeed A, Raza MY (2020) Does financial development and foreign direct investment improve environmental quality? evidence from belt and road countries. Environ Sci and Pollut Res, 27: 23586-23601. https://doi.org/10.1007/s11356-020-08748-7

Ahmed S, Alam K, Rashid A, Gow J (2020) Militarisation, energy consumption, CO2 emissions and economic growth in Myanmar. Def and Peace Economics, 31:615-641. https://doi.org/10.1080/10242694.2018.1560566

Alahmad B, Shakarchi AF, Khraishah H, Alseaidan M, Gasana J, Al-Hemoud A, Koutrakis P, Fox, M. (2020). Extreme temperatures and mortality in Kuwait: who is vulnerable?. Sci of the Total Environ, 732:139289. https://doi.org/10.1016/j.scitotenv.2020.139289 
Alshehry AS, Belloumi M (2017) Study of the environmental Kuznets curve for transport carbon dioxide emissions in Saudi Arabia. Renew and Sustainable Energy Rev 75:13391347. https://doi.org/10.1016/j.rser.2016.11.122

Anwar A, Siddique M, Doğan E, Sharif A (2021) The moderating role of renewable and nonrenewable energy in environment-income nexus for ASEAN countries: evidence from method of moments quantile regression. Renew Energy 164:956-967. https://doi.org/10.1016/j.renene.2020.09.128

Apergis N, Ozturk I (2015) Testing environmental Kuznets curve hypothesis in Asian countries. Ecol Indicators 52:16-22. https://doi.org/10.1016/j.ecolind.2014.11.026

Aziz N, Mihardjo L, Sharif A, Jermsittiparsert K (2020) The role of tourism and renewable energy in testing the environmental kuznets curve in the BRICS countries: fresh evidence from methods of moments quantile regression. Environ Sci and Pollut Res 27:3942739441. https://doi.org/10.1007/s11356-020-10011-y

Bakirtas I, Cetin MA (2017) Revisiting the environmental Kuznets curve and pollution haven hypotheses: MIKTA sample. Environ Sci and Pollut Res, 24:18273-18283. https://doi.org/10.1007/s11356-017-9462-y

Bargaoui SA, Nouri FZ (2017) Dynamic panel data analysis of co2 emissions driving forces. J of Economics Stud and Res 2017: 1-18. https://doi.org/10.5171/2017.947798

Barunik J, Cech F (2021) Measurement of common risks in tails: A panel quantile regression model for financial returns. $J$ of Financial Mark 52:100562. https://doi.org/10.2139/ssrn.3028488

Begum RA, Sohag K, Abdullah SM, Jaafar M (2015) CO2 emissions, energy consumption, economic and population growth in Malaysia. Renew and Sustainable Energy Rev 41:594601. https://doi.org/10.1016/j.rser.2014.07.205

Bildirici M (2017a) The causal link among militarization, economic growth, CO2 emission, and energy consumption. Environ Sci Pollut Res 24:4625-4636. https://doi.org/10.1007/s11356-016-8158-z

Bildirici M (2017b) The effect of militarization on biofuel consumption and CO2 emission. $\mathrm{J}$ Clean Prod 152:420-428. https://doi.org/10.1016/j.jclepro.2017.03.103

Bildirici M (2017c) CO2 emission and militarization in G7 countries: panel cointegration and trivariate causality approaches. Environ Dev Econ 22(6):771-791. https://doi.org/10.1017/S1355770X1700016X

Bildirici M (2017d) Impact of militarization and economic growth on biofuels consumption and co2 emissions: the evidence from Brazil, China, and US. Environ Prog \& Sustainable Energy 37:3. https://doi.org/10.1002/ep

Bilgili F, Kuşkaya S, Awan, A, Türker O (2021) The roles of economic growth and health expenditure on $\mathrm{CO} 2 \mathrm{emissions}$ in selected Asian countries: a quantile regression model approach. Environ Sci and Pollut Res 28:44949-44972. https://doi.org/10.1007/s11356021-13639-6

Birdi A, Dunne P (2001) An econometric analysis of military spending and economic growth in South Africa. Middlesex University Business School (2001). http://carecon.org.uk/UWEMasters/Applied\%20Econometrics/SAeconometrics4.pdf. Accessed 15 February 2022

Bowman M (2010) The role of the banking industry in facilitating climate change mitigation and the transition to a low-carbon global economy. Environ Plan Law J 27:448, https://ssrn.com/abstract=1762562. Accessed 15 February 2022

Brunnschweiler CN (2010) Finance for renewable energy: an empirical analysis of developing and transition economies. Environ Dev Econ 15:241-274. https://doi.org/10.1017/S1355770X1000001X 
Campiglio E (2016) Beyond carbon pricing: the role of banking and monetary policy in financing the transition to a low-carbon economy. Ecol Econ 121:220-230. https://doi.org/10.1016/j.ecolecon.2015.03.020

Can M, Gozgor G (2017) The impact of economic complexity on carbon emissions: evidence from France. Environ Sci Pollut Res 24:16364-16370. https://doi.org/10.1007/s11356017-9219-7

Chen C, Lei Y (2018) The impacts of renewable energy and technological innovation on environment-energy-growth nexus: new evidence from a panel quantile regression. Renew Energy 123:1-14. https://doi.org/10.1016/j.renene.2018.02.026

Chen F, Deng Z, Deng Y, Qiao Z, Lan L, Meng Q, Luo B, Zhang W, Ji K, Qiao X et al (2017) Attributable risk of ambient PM10 on daily mortality and years of life lost in Chengdu, China. Sci of the Total Environ 581-582:426-433. https://doi.org/10.1016/j.scitotenv.2016.12.151

Chen S (2013) Green finance and development of low carbon economy. In: LTLGB 2012. Springer, Berlin, 457-461. https://doi.org/10.1007/978-3-642-34651-4_65

Cole MA, Rayner AJ, Bates JM (1997) The environmental Kuznets curve: an empirical analysis. Environ and Development Economics 2(4):401-416. https://EconPapers.repec.org/RePEc:cup:endeec:v:2:y:1997:i:04:p:401-416_00. Accessed 15 February 2022

Çınar S (2011). Income and CO2 emissions: panel unit root and cointegration. Uludağ J of Economy and Society, 30(2):71-83. https://app.trdizin.gov.tr/publication/paper/detail/TVRJNU5qWXINZz09. Accessed 15 February 2022

Demirhan H (2020) Impact of increasing temperature anomalies and carbon dioxide emissions on wheat production. Sci of the Total Environ 741:139616. https://doi.org/10.1016/j.scitotenv.2020.139616

Dong H, Xue M, Xiao Y, Liu Y (2021) Do carbon emissions impact the health of residents? considering China's industrialization and urbanization. Sci of the Total Environ, 758:143688. https://doi.org/10.1016/j.scitotenv.2020.143688

D'Orazio P, Dirks MW (2020) The impact of climate-related fiscal and financial policies on carbon emissions in G20 countries: a panel quantile regression approach, Ruhr Economic Pap, No. 860, ISBN 978-3-86788-996-4, RWI - Leibniz-Institut für Wirtschaftsforschung, Essen. https://doi.org/10.4419/86788996

Dumortier J, Elobeid A (2021) Effects of a carbon tax in the United States on agricultural markets and carbon emissions from land-use change. Land Use Policy 103:105320. https://doi.org/10.1016/j.landusepol.2021.105320

Ehigiamusoe KU, Lean HH (2019) Effects of energy consumption, economic growth, and financial development on carbon emissions: evidence from heterogeneous income groups. Environ Sci Pollut Res, 26(22):22611-22624. https://doi.org/10.1007/s11356-019-053095

Gokmenoglu KK, Taspinar N, Rahman MM (2021) Military expenditure, financial development and environmental degradation in Turkey: a comparison of $\mathrm{CO} 2$ emissions and ecological footprint. International $J$ of Finance \& Economics 26:986-997. https://doi.org/10.1002/ijfe.1831

Gomez M, Rodriguez JC (2020) The ecological footprint and kuznets environmental curve in the USMCA countries: a method of moments quantile regression analysis. Energies 13(6650):1-15. https://doi.org/10.3390/en13246650

Greene WH (2019) Econometric analysis, 8th Edition, Pearson Education: Essex.

Grossman GM, Krueger AB (1991) Environmental impacts of a North American free trade agreement. NBER Working Pap 3914. https://doi.org/10.3386/w3914 
687

688

689

690

691

692

693

694

695

696

697

698

699

700

701

702

703

704

705

706

707

708

709

710

711

712

713

714

715

716

717

718

719

720

721

722

723

724

725

726

727

728

729

730

731

732

733

734

735

Gujarati D (2011) Econometrics by example. Palgrave Macmillan: London.

Gul S, Zou X, Hassan CH, Azam M, Zaman K (2015) Causal nexus between energy consumption and carbon dioxide emission for Malaysia using maximum entropy bootstrap approach. Environ Sci Pollut Res 22:19773-19785. https://doi.org/10.1007/s11356-015$5185-0$

Hansen J, Kharecha P, Sato M, Masson-Delmotte V, Ackerman F (2013) Assessing “'dangerous climate change": required reduction of carbon emissions to protect young people. Future $\begin{array}{llll}\text { Generations Nat } & \text { (PLoS }\end{array}$ https://doi.org/10.1371/journal.pone.0081648

Hapsoro D, Ambarwati A (2018) Antecedents and consequences of carbon emissions' disclosure: case study of oil, gas and coal companies in non-annex 1 member countries. $\mathrm{J}$ of Indonesian Economy and Business, 33(2):99 - 111. https://doi.org/10.22146/jieb.28756

Harbaugh WT, Levinson A, Wilson DM (2002) Reexamining the empirical evidence for an environmental Kuznets curve. Rev of Economics and Stat 84(3):541-551. https://EconPapers.repec.org/RePEc:tpr:restat:v:84:y:2002:i:3:p:541-551. Accessed 15 February 2022

He Z, Xu S, Shen W, Long R, Chen H (2017) Impact of urbanization on energy related CO2 emission at different development levels: regional difference in China based on panel estimation. $\mathrm{J}$ of Clean Prod 140:1719-1730. https://doi.org/10.1016/J.JCLEPRO.2016.08.155

Hsien LY, Ling HY, Hui CT (2017) Does hot money impact stock and exchange rate markets on China?. Asian Academy of Manag J of Account and Finance (AAMJAF), 13(2):95108. http://web.usm.my/journal/aamjaf/aamjaf13022017/aamjaf13022017_5.pdf. Accessed 15 February 2022

Huang Y, Zhu H, Zhang Z (2020) The heterogeneous effect of driving factors on carbon emission intensity in the Chinese transport sector: evidence from dynamic panel quantile regression. Sci of the Total Environ 727:138578. https://doi.org/10.1016/j.scitotenv.2020.138578

Ivanova E, Masarova J (2018) Performance evaluation of the Visegrad Group countries. Economic Res-Ekonomska Istraživanja 31(1):270-289. https://doi.org/10.1080/1331677X.2018.1429944

Iwata H, Okada K, Samreth S (2010) Empirical study on the environmental kuznets curve for co2 in France: the role of nuclear energy. Energy Policy 38(8):4057-4063. https://doi.org/10.1016/j.enpol.2010.03.031

Jalil A, Feridun M (2011) The impact of growth, energy and financial development on the environment in China: a cointegration analysis. Energy Econ 33(2):284-291. https://doi.org/10.1016/j.eneco.2010.10.003

Jaunky VC (2011) The CO2 emissions-income nexus: evidence from rich countries. Energy Policy 39:1228-1240. https://doi.org/10.1016/j.enpol.2010.11.050

Jebli MB, Youssef SB, Öztürk İ (2016) Testing environmental kuznets curve hypothesis: The role of renewable and non-renewable energy consumption and trade in OECD countries. Ecol Indicators 60:824-831. https://doi.org/10.1016/j.ecolind.2015.08.031

Jiang Q, Khattak SI, Rahman ZU (2021) Measuring the simultaneous effects of electricity consumption and production on carbon dioxide emissions (CO2e) in China: New evidence from an EKC-based assessment. Energy 229:120616. https://doi.org/10.1016/j.energy.2021.120616

Johnstone P, McLeish C (2020) World wars and the age of oil: Exploring directionality in deep energy transitions. Energy Res \& Soc Sci 69:101732. https://doi.org/10.1016/j.erss.2020.101732 
Khan H, Khan I, Binh TT (2020) The heterogeneity of renewable energy consumption, carbon emission and financial development in the globe: a panel quantile regression approach. Energy Reports 6:859-867. https://doi.org/10.1016/j.egyr.2020.04.002

Khraief N, Shahbaz M, Heshmati A, Azam M (2020) Are unemployment rates in OECD countries stationary? evidence from univariate and panel unit root tests. The North Am J of Economics and Finance 51:100838. https://doi.org/10.1016/j.najef.2018.08.021

Koçak E, Ulucak R, Ulucak ZŞ (2020) The impact of tourism developments on CO2 emissions: an advanced panel data estimation. Tour Manag Perspect 33:100611. https://doi.org/10.1016/j.tmp.2019.100611

Koenker R (2005) Quantile regression. New York: CambridgeUniversity Press.

Kvaloy B, Finseraas H, Listhaug O (2012) The publics' concern for global warming: a crossnational study of 47 countries. $J$ of Peace Res 49(1):11-22. https://doi.org/10.1177/0022343311425841

Lahiani A (2020) Is financial development good for the environment? an asymmetric analysis with CO2 emissions in China. Environ Sci and Pollut Res 27:7901-7909. https://doi.org/10.1007/s11356-019-07467-y

Leal PH, Marques AC (2020) Rediscovering the EKC hypothesis for the 20 highest CO2 emitters among OECD countries by level of globalization. International Economics 164:36-47. https://doi.org/10.1016/j.inteco.2020.07.001

Levine R, Lin C, Wang Z, Xie W (2018) Bank liquidity, credit supply, and the environment. National Bur of Economic Res 24375. https://doi.org/10.3386/w24375

Li P, Ouyang Y (2019) The dynamic impacts of financial development and human capital on $\mathrm{CO} 2$ emission intensity in China: an ARDL approach. $\mathrm{J}$ of Bus Economics and Manag 20(5):939-957. https://doi.org/10.3846/jbem.2019.10509

Lin B, Xu B (2018) Factors affecting CO2 emissions in China's agriculture sector: a quantile regression. Renew and Sustainable Energy Rev 94:15-27. https://doi.org/10.1016/j.rser.2018.05.065

Loganathan N, Laxman LKP, Mardani A, Streimikiene D, Hassan AAG (2019) Golden age population, healthy environment, growth and poverty: Are Malaysia really in a sustainable condition?. Problemy Ekorozwoju/Problems of Sustainable Development 14(2):201-212. https://ekorozwoj.pollub.pl/no28/w.pdf. Accessed 15 February 2022

Lv Z, Li SS (2021) How financial development affects CO2 emissions: a spatial econometric analysis. J of Environ Manag 277:111397. https://doi.org/10.1016/j.jenvman.2020.111397

Machado JAF, Silva JMCS (2019). Quantiles via moments. Journal of Econometrics, 213(1):145-173. https://doi.org/10.1016/j.jeconom.2019.04.009

Mercan M, Peker O, Göçer İ (2015) The inflationary effect of the increases in crude oil prices: structural breaks dynamıc panel data analysis for selected OECD countries. Doğuş Universty J 16(2):123-137. https://hdl.handle.net/11376/2262. Accessed 15 February 2022

Mikayilov JI, Mukhtarov S, Dinçer H, Yüksel S, Aydın R (2020) Elasticity analysis of fossil energy sources for sustainable economies: A case of gasoline consumption in Turkey. Energies13(3):731. https://doi.org/10.3390/en13030731

Nasir MA, Huynh TLD, Tram HTX (2019) Role of financial development, economic growth $\&$ foreign direct investment in driving climate change: a case of emerging ASEAN. $J$ Environ Manag 242: 131-141. https://doi.org/10.1016/j.jenvman.2019.03.112

Neog Y, Yadava AK (2020) Nexus among CO2 emissions, remittances, and financial development: A NARDL approach for India. Environ Sci and Pollut Res 27:44470-44481. https://doi.org/10.1007/s11356-020-10198-0

Ni ZX, Wang DZ, Xue WJ (2015) Investor sentiment and its nonlinear effect on stock returnsNew evidence from the Chinese stock market based on panel quantile regression model. Economic Modelling 50:266-274. https://doi.org/10.1016/j.econmod.2015.07.007 
Nwani C, Omoke CP (2020) Does bank credit to the private sector promote low-carbon development in Brazil? an extended STIRPAT analysis using dynamic ARDL simulations. Environ Sci and Pollut Res 27:31408-31426. https://doi.org/10.1007/s11356-020-09415-7

Ozcan B (2013) The nexus between carbon emissions, energy consumption and economic growth in Middle East Countries: a panel data analysis. Energy Policy 62:1138-1147. https://doi.org/10.1016/j.enpol.2013.07.016

Panayotou T (2003) Economics growth and environment. Economic Survey of Europe 2:4572. https://unece.org/fileadmin/DAM/ead/pub/032/032_c2.pdf. Accessed 15 February 2022

Papiez M (2013) CO2 emissions, energy consumption and economic growth in the Visegrad Group countries: a panel data analysis. 31st International Conference on Mathematical Methods in Economics 696-701. http://www.katstat.uek.krakow.pl/wpcontent/uploads/2014/06/CO-2-emissions-energy-consumption-and-economicgrowth.pdf. Accessed 15 February 2022

Rana R, Sharma M (2019) Dynamic causality testing for EKC hypothesis, pollution haven hypothesis and international trade in India. The $\mathrm{J}$ of International Trade \& Economic Development 28(3):348-364. https://doi.org/10.1080/09638199.2018.1542451

Rehman A, Ma H, Ahmad M, Irfan M, Traore O, Chandio AA (2021) Towards environmental sustainability: devolving the influence of carbon dioxide emission to population growth, climate change, forestry, livestock and crops production in Pakistan. Ecological Indicators 125:107460. https://doi.org/10.1016/j.ecolind.2021.107460

Robalino-López A, Mena-Nieto Á, García-Ramos JE, Golpe AA (2015) Studying the relationship between economic growth, co2 emissions, and the environmental kuznets curve in Venezuela (1980-2025). Renew and Sustainable Energy Rev 41:602-614. https://doi.org/10.1016/j.rser.2014.08.081

Rossati A (2017). Global warming and its health impact. Int J Occup Environ Med 8:7-20. https://doi.org/10.15171/ijoem.2017.963

Samour A, Isıksal AZ, Resatoglu NG (2019) Testing the impact of banking sector development on Turkey's CO2 emissions. Appl Ecology and Environmental Res 17(3):6497-6513. http://dx.doi.org/10.15666/aeer/1703_64976513

Sana E, Neila B (2016) The Relationship between military expenditure, military personnel, economic growth, and the environment. World Academy of Sci Eng and Technol International $J$ of Economics and Manag Eng 10(4):1059-1064. http://doi.org/10.5281/zenodo.1112109

Schmidt A (2016) Friends forever? the role of the Visegrad group and European integration. Politics in Central Europe 12(3):113-140. http://doi.org/10.1515/pce-2016-0019

Shafik N, Bandyopadhyay S (1992) Economic growth and environmental quality: Time series and cross-country evidence. The World Bank Policy Res Work Pap 1-50. http://documents1.worldbank.org/curated/en/833431468739515725/pdf/multi-page.pdf. Accessed 15 February 2022

Shahbaz M. (2019). Globalization-emissions nexus: testing the EKC hypothesis in Next-11 countries. Glob Bus Rev 1-26. https://doi.org/10.1177/0972150919858490

Shahbaz M, Mahalik MK, Shah SH, Sato JR (2016) Time-varying analysis of co2 emissions, energy consumption, and economic growth nexus: statistical experience in Next 11 countries. Energy Policy 98:33-48. https://doi.org/10.1016/j.enpol.2016.08.011

Shahbaz M, Tiwari AK, Nasir M (2013) The effects of financial development, economic growth, coal consumption and trade openness on $\mathrm{CO} 2$ emissions in South Africa. Energy Pol 61:1452-1459. https://doi.org/10.1016/j.enpol.2013.07.006 
Singh BP, Kannadhasan M (2020) Corruption and capital structure in emerging markets: a panel quantile regression approach. $\mathrm{J}$ of Behav and Exp Finance 28:100417. https://doi.org/10.1016/j.jbef.2020.100417

Solarin SA, Al-Mulali U, Ozturk I (2018) Determinants of pollution and the role of the military sector: evidence from a maximum likelihood approach with two structural breaks in the USA. Environ Sci Pollut Res 25:30949-30961. https://doi.org/10.1007/s11356-018-30605

Song T, Zheng T, Tong L (2008) An empirical test of the environmental Kuznets curve in China: a panel cointegration approach. China Economic Rev 19(3):381-392. https://doi.org/10.1016/j.chieco.2007.10.001

Su X, Lin F, Hu M, Deng C (2019) Quantile regression analysis of Guangdong carbon trading market. Reports on Economics and Finance 5(1):81-87. https://doi.org/10.12988/ref.2019.944

Sundblad L, Biel A, Garling T (2014) Intention to change activities that reduce carbon dioxide emissions related to worry about global climate change consequences Inquiétude à propos $\mathrm{du}$ changement climatique et intention de changer ses habitudes de consommation génératrice de co2. Eur Rev of Appl Psychology 64(1):13-17. https://doi.org/10.1016/j.erap.2011.12.001

Tamazian A, Juan PC, Krishna CV (2009) Does higher economic and financial development lead to environmental degradation: evidence from BRIC countries. Energy Policy 37(1):246-253. https://doi.org/10.1016/j.enpol.2008.08.025

Tatoğlu FY (2018). Panel zaman serileri analizi. Beta Yayınları, İstanbul.

Tenaw D, Beyene AD (2021) Environmental sustainability and economic development in subSaharan Africa: a modified EKC hypothesis. Renew and Sustainable Energy Rev 143:110897. https://doi.org/10.1016/j.rser.2021.110897

Tian Y, Chen W, Zhu S (2017) Does financial macroenvironment impact on carbon intensity: evidence from ARDL-ECM model in China. Nat Hazards 88(2):759-777. https://doi.org/10.1007/s11069-017-2925-0

Ullah S, Andlib Z, Majeed MT, Sohail S, Chishti MZ (2021) Asymmetric effects of militarization on economic growth and environmental degradation: fresh evidence from Pakistan and India. Environ Sci and Pollut Res 28:9484-9497. https://doi.org/10.1007/s11356-020-11142-y

Usman O, Bekun FV, Ike GN (2020) Democracy and tourism demand in European countries: does environmental performance matter?. Environ Sci and Pollut Res 27:38353-38359. https://doi.org/10.1007/s11356-020-10258-5

Ustaoglu A, Yaras A, Sutcu M, Gencel O (2021) Investigation of the residential building having novel environment-friendly construction materials with enhanced energy performance in diverse climate regions: cost-efficient, low-energy and low-carbon emission. J of Build Eng 43:102617. https://doi.org/10.1016/j.jobe.2021.102617

Velepucha PAE, Chamba JAM, Mendoza NAA, Luna TLO, Rojas NSS, Furniss MJ, Howe, C, Mendoza ZHA (2016)Tropical ecosystems vulnerability to climate change in southern Ecuador.Tropical Conservation Sci 1-17. https://doi.org/10.1177/1940082916668007

Wang KH, Su CW, Lobont OR, Umar M (2021) Whether crude oil dependence and CO2 emissions influence military expenditure in net oil importing countries?. Energy Policy 153:112281. https://doi.org/10.1016/j.enpol.2021.112281

Wang SS, Zhou DQ, Zhou P, Wang QW (2011) CO2 emissions, energy consumption and economic growth in China: a panel data analysis. Policy Energy 39:4870-4875. https://doi.org/10.1016/j.enpol.2011.06.032 
Wang Y, Zhangi X, Kubota J, Zhu X, Lu G (2015) A semi-parametric panel data analysis on the urbanization-carbon emissions nexus for OECD countries. Renew and Sustainable Energy Rev 48:704-709. https://doi.org/10.1016/j.rser.2015.04.046

$\mathrm{Xu}$ B, Lin B (2020) Investigating drivers of CO2 emission in China's heavy industry: a quantile regression analysis. Energy 206:1-13. https://doi.org/10.1016/j.energy.2020.118159

Xu Z, Baloch MA, Meng F, Zhang J, Mahmood Z (2018) Nexus between financial development and $\mathrm{CO} 2$ emissions in Saudi Arabia: analyzing the role of globalization. Environ Sci Pollut Res 25(28):28378-28390. https://doi.org/10.1007/s11356-018-2876-3

Yang B, Ali M, Nazir MR, Ullah W, Qayyum M (2020) Financial instability and CO2 emissions: cross-country evidence. Air Quality, Atmos \& Health 13:459-468. https://doi.org/10.1007/s11869-020-00809-7

You W, Guo Y, Zhu H, Tang Y (2017) Oil price shocks, economic uncertainty and industry stock returns in China: asymmetric effects with quantile regression. Energy Economics 68:1-18. https://doi.org/10.1016/j.eneco.2017.09.007

Zhu H, Duan L, Guo Y, Yu K (2016) The effects of FDI, economic growth and energy consumption on carbon emissions in ASEAN-5: evidence from panel quantile regression. Economic Modelling 58:237-248. https://doi.org/10.1016/j.econmod.2016.05.003 
Figures

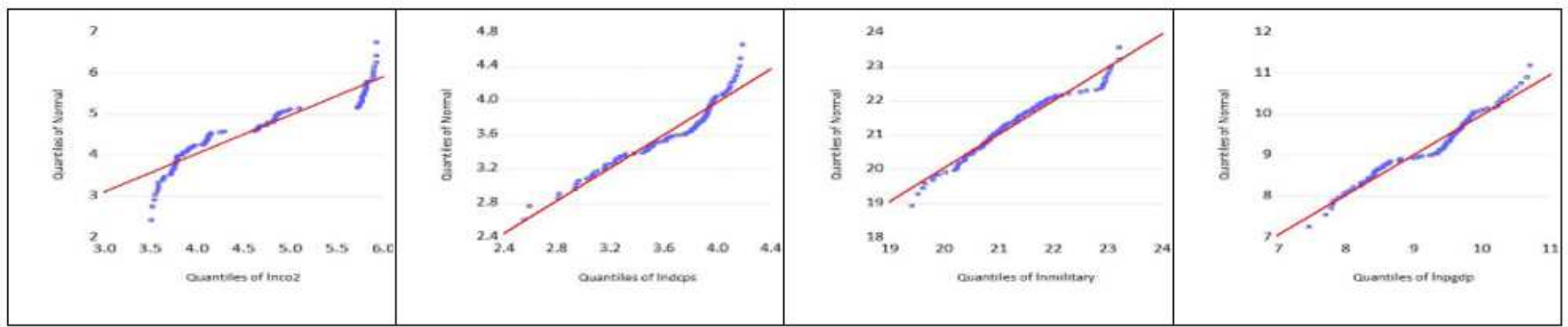

(a)

(b)

(c)

(d)

Figure 1

Q-Q probability distribution plots of variables

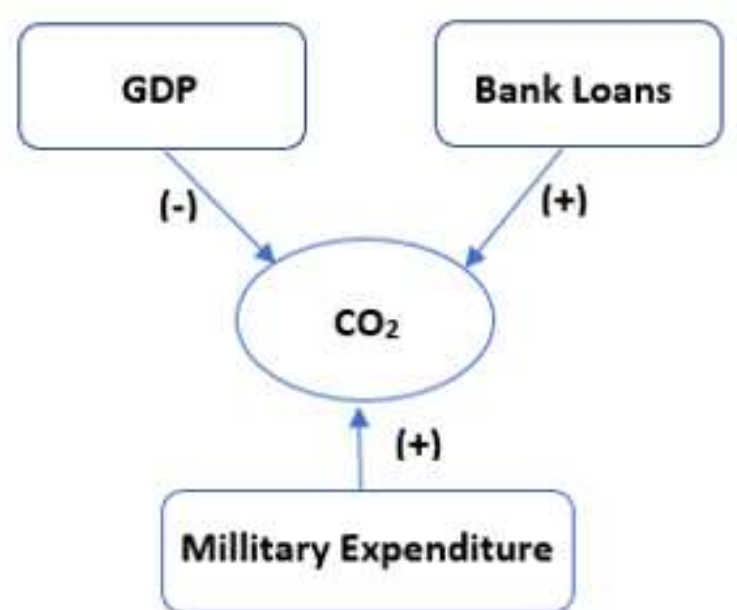

Figure 2

Effect of variables on carbon emissions 